\title{
Pengaruh Kebijakan Perubahan Tarif PPH Final Terhadap Kepatuhan Wajib Pajak Pelaku UMKM
}

\author{
Cinantya Kumaratih1*, Budi Ispriyarso² \\ 1Program Studi Magister Ilmu Hukum, Fakultas Hukum, Universitas Diponegoro \\ 2Fakultas Hukum, Universitas Diponegoro \\ *cinantya27@gmail.com
}

\begin{abstract}
In Indonesia, funds for development can be obtained from tax collection as one of the country's main sources of income. Micro, Small and Medium Enterprises (MSMEs) are one of the economic sectors that have great potential as a source of state revenue through tax collection. For this reason, the government issues Government Regulations that regulate final Income Tax rates for MSMEs. This study aims to analyze the effect of income tax reduction policies on the level of compliance of MSMEs as taxpayers. This research uses a qualitative research method, with an empirical juridical approach. This study shows a policy regarding the MSME income tax rate of $1 \%$ through Government Regulation No. 46 of 2013. However, the enactment of this regulation experienced pros and cons among the people. As a result, in 2018 the government changed the tax rate by $0.5 \%$ through Government Regulation No. 23 of 2018. This policy on reducing income tax rates for MSMEs has an influence on the level of compliance of MSMEs as taxpayers. Research conducted at the West Semarang Pratama Tax Service Office showed an increase in compliance of MSME actors in carrying out their tax obligations.
\end{abstract}

\section{Keywords: Income tax; Taxpayer Compliance; MSME.}

\begin{abstract}
ABSTRAK
Di Indonesia, dana untuk pembangunan dapat diperoleh atas pemungutan pajak sebagai salah satu sumber pendapatan utama negara. Usaha Mikro Kecil dan Menengah (UMKM) adalah salah satu sektor perekonomian yang memiliki potensi besar sebagai sumber pendapatan negara melalui pemungutan pajak. Untuk itu pemerintah menerbitkan Peraturan Pemerintah yang mengatur tarif Pajak Penghasilan yang bersifat final kepada UMKM. Penelitian ini bertujuan untuk menganalisis pengaruh kebijakan penurunan pajak penghasilan terhadap tingkat kepatuhan UMKM sebagai Wajib Pajak. Penelitian ini menggunakan metode penelitian kualitatif, dengan pendekatan yuridis empiris. Penelitian ini menunjukan adanya kebijakan mengenai tarif pajak penghasilan UMKM sebesar 1\% melalui Peraturan Pemerintah No. 46 tahun 2013. Namun, berlakunya peraturan ini mengalami pro dan kontra dikalangan masyarakat. Akibatnya pada tahun 2018 pemerintah merubah besaran tarif pajak sebesar 0,5\% melalui Peraturan Pemerintah No. 23 Tahun 2018. Kebijakan mengenai penurunan tarif pajak penghasilan bagi UMKM ini memberikan pengaruh terhadap tingkat kepatuhan UMKM sebagai Wajib Pajak. Penelitian yang dilakukan di Kantor Pelayanan Pajak Pratama Semarang Barat menunjukan adanya peningkatan kepatuhan pelaku UMKM dalam melakukan kewajiban pajaknya.
\end{abstract}

Kata Kunci: Pajak Penghasilan; Kepatuhan Wajib Pajak; UMKM. 
Jurnal Pembangunan Hukum Indonesia

Volume 2, Nomor 2, Tahun 2020
Program Studi Magister Ilmu Hukum Fakultas Hukum Universitas Diponegoro

\section{A. PENDAHULUAN}

Pembangunan di segala bidang yang dilaksanakan Indonesia saat ini bertujuan untuk meningkatkan kesejahteraan masyarakat. Pembiayaan pembangunan tersebut memerlukan dana yang cukup banyak sebagai syarat agar pembangunan dapat terwujud. Dana tersebut dapat diambil atas pemungutan pajak sebagai salah satu sumber pendapatan utama baik yang bersumber dari dalam negeri maupun pajak perdagangan internasional. Adanya pendapatan dari sektor pajak yang masuk ke kas negara diharapkan dapat menjadi tulang punggung pendapatan negara untuk mencukupi segala kebutuhan Indonesia (Purnawan, \& Adillah, 2014).

Ketentuan suatu perpajakan di Indonesia telah memiliki payung hukum, hal ini sebagaimana telah diatur pada Pasal 23 A Undang-undang Dasar Negara Republik Indonesia Tahun 1945 yang menyebutkan "pajak dan pungutan lain bersifat memaksa untuk keperluan negara diatur dengan undang-undang". Pasal 23 A UUD NRI 1945 tersebut menentukan bahwa dasar hukum dari pemungutan pajak yang dibebankan kepada rakyat atau Wajib Pajak adalah berdasarkan undang-undang sehingga menjamin adanya kepastian hukum. Hal ini mengandung arti bahwa pajak merupakan peralihan kekayaan dari rakyat kepada pemerintah yang tidak ada imbalannya secara langsung dapat ditunjuk (Sa'adah, 2014).

Pemerintah yang memiliki kewenangan tertinggi dalam pengelolaan negara dengan mempunyai hak untuk menjaga agar kas negara terisi dengan hasil pemungutan pajak dari Wajib Pajak. Pajak merupakan jenis pembayaran yang bersifat wajib dan dikenakan kepada seluruh Wajib Pajak yang kemudian hasilnya digunakan untuk masyarakat itu sendiri.

Aturan umum Perpajakan di Indonesia diatur oleh Undang-Undang Nomor 16 Tahun 2009 tentang Perubahan Terakhir Atas Undang-undang Nomor 6 Tahun 1983 tentang Ketentuan Umum dan Tata Cara Perpajakan, dasar hukum ini memiliki fungsi untuk mengatur Wajib Pajak maupun Pemerintah sebagai pemungut pajak agar tidak bersikap sewenangwenang dalam melakukan pemungutan pajak.

Indonesia pernah mengalami kondisi krisis ekonomi yang menyebabkan jatuhnya perekonomian nasional. Banyak para usahawan yang memiliki usaha dengan skala besar pada berbagai sektor termasuk industri, perdagangan, dan jasa yang mengalami terhenti aktifitasnya pada tahun 1998. Namun Usaha Mikro Kecil dan Menengah (UMKM) dapat bertahan sebagai penolong perekonomian akibat adanya krisis moneter pada berbagai sektor ekonomi (Ananda, \& Susilowati, 2015). Berkaitan dengan hal tersebut UMKM mempunyai peran yang penting dalam memperbaiki sektor perekonomian di Indonesia terutama sebagai Wajib Pajak dalam pemasukan kas negara.

Pemerintah selaku pengelola pemungutan pajak terus mendorong pelaku UMKM untuk taat pada kewajiban perpajakannya, hal ini dapat dilihat dengan beberapa kebijakan yang mendorong 
Jurnal Pembangunan Hukum Indonesia

Volume 2, Nomor 2, Tahun 2020
Program Studi Magister Ilmu Hukum Fakultas Hukum Universitas Diponegoro penerimaan Pajak yaitu ketentuan perpajakan yang mengatur tarif khusus PPh untuk UMKM.

Terdapat kesamaan pengertian tentang pajak yang diungkapkan oleh beberapa ahli. Seperti yang diungkapkan oleh Suparman Sumadwijaya, Prof. Dr. MJH. Smeeths. Dimana Suparman Sumadwijaya, mengemukakan bahwa pajak adalah iuran wajib berupa barang yang dipungut oleh pengusaha berdasarkan Norma hukum, guna menutup biaya produksi barang dan jasa kolektif dalam mencapai kesejahteraan umum" (Kumaratih, Ispriyarso \& Sa'adah, 2018); kemudian Prof. Dr. MJH. Smeeths, pajak adalah prestasi pemerintah yang terutang melalui norma-norma umum, dan yang dapat dipaksakan tanpa adanya kontra prestasi yang dapat ditunjukkan dalam hal individual, maksudnya adalah membiayai pengeluaran pemerintah" (Bohari, 2016).

Pasal 1 angka 1 Undang-Undang Republik Indonesia Nomor 28 Tahun 2007 tentang Perubahan Ketiga Atas Undang-Undang Nomor 6 Tahun 1983 tentang Ketentuan Umum Dan Tata Cara Perpajakan (UU KUP) menyebutkan "Pajak adalah kontribusi wajib kepada negara yang terutang oleh orang pribadi atau badan yang bersifat memaksa berdasarkan Undang-Undang, dengan tidak mendapatkan imbalan secara langsung dan digunakan untuk keperluan negara bagi sebesarbesarnya kemakmuran rakyat".

Pajak dapat dikatagorikan menjadi dua jenis Pajak, katagori tersebut ditinjau dari aspek sifat, cara pemungutan maupun dari kewenangannya. Berdasarkan kewenangannya Pajak dapat dibedakan menjadi Pajak Pusat dan Pajak Daerah. Pajak Pusat ialah pajak yang ditetapkan oleh Pemerintah Pusat berdasarkan undang-undang dan hasilnya digunakan untuk membiayai berbagai pembangunan dan pengeluaran Pemerintah Pusat (Siahaan, 2010). Pungutan pajak yang dapat dilakukan oleh Pemerintah Pusat memiliki sifat yang menyeluruh, dalam arti lain setiap masyarakat di Indonesia yang telah memenuhi syarat menjadi Wajib Pajak dapat dipungut pajak (Sulastyawati, Aravik, \& Yunus, 2019).

Selaras dengan pengertian pajak menurut para ahli dan pengertin pajak berdasarkan UU KUP, maka sangatlah benar pernyataan bahwa pajak merupakan iuran kas negara yang dipungut berdasarkan undang-undang, oleh sebab itu pemungutan pajak dapat dilakukan secara paksa (Ispriyarso, 2015).

Selain itu, pajak secara langsung memiliki Fungsi Reguleren serta Fungsi Budgetair (Kusuma, 2016). Fungsi reguleren merupakan alat pendorong ataupun alat penghambat dalam mencapai tujuan di luar bidang keuangan negara. Adanya fungsi reguleren (mengatur), mengakibatkan pemerintah Indonesia bisa mengatur pertumbuhan ekonomi melalui kebijaksanaan pajak. Dengan fungsi mengatur tersebut, pajak digunakan sebagai alat untuk mencapai tujuan suatu negara yaitu untuk kemakmuran rakyat. Kemudian fungsi pajak sebagai fungsi budgetair (finansial) merupakan fungsi anggaran sebagai sumber pendapatan negara. Maka 
Jurnal Pembangunan Hukum Indonesia

Volume 2, Nomor 2, Tahun 2020
Program Studi Magister Ilmu Hukum Fakultas Hukum Universitas Diponegoro dari itu, fungsi budgetair adalah sarana untuk menarik dana dari masyarakat (Kusuma, 2016).

Selain fungsi budgetair dan fungsi reguleren, pajak juga memiliki Fungsi Stabilitas dan Fungsi Retribusi Pendapatan. Fungsi stabilitas dimaksudkan pajak adalah sebagai penerimaan negara dapat digunakan untuk menjalankan kebijakan-kebijakan pemerintah. Fungsi retribusi pendapatan diartikan bahwa penerimaan negara dari pajak digunakan untuk membiayai pengeluaran umum dan pembangunan nasional sehingga dapat membuka kesempatan kerja dengan tujuan untuk meningkatkan pendapatan masyarakat (Maharatih, 2019).

Kemudian terkait Ekonomi mikro, kecil, dan menengah adalah tiga (3) kelopok ekonomi yang dapat menyentuh semua lapisan masyarakat di seluruh negeri, dari perkotaan hingga ke pedesaan yang terpencil sekalipun (Taufik, 2017). Perbedaan kegiatan ekonomi tersebut membentuk suatu tata ekonomi yang secara structural sangat berperan dalam kegiatan ekonomi nasional (Endrianto, 2015). Kegiatan usaha yang berbasis Usaha Mikro, Kecil dan Menengah (UMKM) sudah sejak lama mendominasi perekonomian Indonesia dan terus berkembang (Disemadi \& Roisah, 2019). Hal ini karena seiring dengan kemudahan dan fasilitas yang diberikan pemerintah dari sisi informasi maupun bantuan kredit yang disalurkan (Suci, 2017).

Di Indonesia dasar hukum terkait UMKM terdapat dalam Undang-Undang Nomor 20 Tahun 2008 tentang Usaha Mikro, Kecil, dan Menengah (UU UMKM). Kebijakan hadirnya UU UMKM didasari adanya pembangunan nasional bertujuan untuk mewujudkan masyarakat adil dan makmuryang merata material dan spiritual berdasarkan Pancasila dan UUD NRI 1945 (Suyatna, 2010). Pembangunan nasional yang mencakup seluruh aspek kehidupan bangsa diselenggarakan bersama oleh masyarakat dan pemerintah (Mulyadi, 2018). Masyarakat menjadi pelaku utama pembangunan, dan pemerintah berkewajiban mengarahkan, membimbing, melindungi, serta menumbuhkan suasana dan iklim yang menunjang.

Pelaku UMKM sebagai Wajib Pajak yang berpotensi dalam pendapatan kas negara melalui pajak, mengakibatkan pemerintah mengeluarkan kebijakan pajak teruntuk UMKM melalui Peraturan Pemerintah Nomor 46 tahun 2013 tentang Pajak Penghasilan Atas Penghasilan Dari Usaha Yang Diterima Atau Diperoleh Wajib Pajak Yang Memiliki Peredaran Bruto Tertentu (PP No. 46 tahun 2013). PP No. 46 tahun 2013 ini menerapkan pajak 1\% bagi UMKM. Terjadi pro dan kontra di kalangan masyarakat mengenai PP ini yang dinilai sebagai bentuk penindasan pemerintah dengan kedok legislasi penyederhanaan pajak penghasilan (PPh) terhadap pengusaha kecil (Maharatih, 2019).

Sehingga, Juni 2018 Presiden Joko Widodo meluncurkan tarif pajak penghasilan (PPh) final yang baru bagi pelaku UMKM (Sari, 2018). Peraturan Pemerintah ini diterbitkan sebagai masa pembelajaran bagi Wajib Pajak yang memiliki peredaran bruto tertentu untuk dapat menyelenggarakan pembukuan sebelum dikenai PPh 
Jurnal Pembangunan Hukum Indonesia

Volume 2, Nomor 2, Tahun 2020
Program Studi Magister Ilmu Hukum Fakultas Hukum Universitas Diponegoro final. Sehingga Wajib Pajak akan lebih mudah dalam melaksanakan dan memenuhi kewajiban perpajakan. Alasan diterbitkannya Peraturan Pemerintah ini untuk mendorong masyarakat agar lebih berperan serta dalam kegiatan ekonomi formal, dengan cara memberikan kemudahan jangka waktu tertentu kepada Wajib Pajak yang memiliki peredaran bruto tertentu dalam melaksanakan kewajiban perpajakan (Maharatih, 2019).

Di samping itu, dikeluarkannya Peraturan Pemerintah ini diharapkan memberikan keadilan kepada Wajib Pajak yang memiliki peredaran bruto tertentu yang telah mampu melakukan pembukuan, sehingga Wajib Pajak dapat memilih untuk dikenai PPh berdasarkan tarif umum UU Pajak Penghasilan.

Adapun tarif PPh final yang baru sebesar 0,5\% berlaku mulai 1 Juli 2018 hingga jangka waktu tertentu. Penetapan besaran tarif UMKM yang baru tertuang dalam Peraturan Pemerintah Nomor 23 Tahun 2018 tentang Pajak Penghasilan atas Penghasilan Usaha Yang Diterima atau Diperoleh Wajib Pajak yang Memiliki Peredaran Bruto Tertentu (PP No. 23 Tahun 2018). Peraturan tersebut menggantikan peraturan sebelumnya, yaitu PP No. 46 Tahun 2013 dengan tarif PPh final UMKM sebesar 1\% yang dihitung berdasarkan pendapatan bruto (omzet)-nya diperuntukkan bagi UMKM yang beromzet kurang dari Rp. 4,8 miliar dalam setahun. Diharapkan dari kebijakan penurunan tarif PPh Final UMKM di Indonesia dapat lebih berperan aktif, berkembang dan sadar akan kewajiban perpajakannya.
Berdasarkan uraian dalam latar belakang di atas, maka dapat di rumuskan permasalahan sebagai berikut: 1). Bagaimana kebijakan perubahan tarif Pajak Penghasilan (PPh) Final terhadap pelaku UMKM di Kantor Pelayanan Pajak Pratama Semarang Barat?; dan 2). Bagaimana pengaruh kebijakan perubahan tarif Pajak Penghasilan (PPh) Final terhadap tingkat kepatuhan Wajib Pajak pelaku UMKM di Kota Semarang Barat?

Mengingat penelitian yang berfokus pada Pajak Penghasilan atau PPh telah dilakukan sebelumnya seperti oleh Ni Wayan Maharatih yang berfokus pada studi kritis tentang tarif PPh final 1\% bagi UMKM (Maharatih, 2019); Amin purnawan yang berfokus pada rekonstruksi pemungunat PPh badan yang berbasis nilai keadilan (Purnawan, 2011); Imas Sholihah yang berfokus pada kebijakan pengampunan pajak dalam upaya mengatasi penggelapan pajak di Indonesia (Sholihah, 2017); Amin Purnawan, Akhmad Khisni dan Aryani Witasari yang berfokus pada politik hukum pengenaan PPh berbasis UMKM dengan dasar nilai keadilan untuk meningkatkan Kepatuhan Pajak dalam Era Revolusi Industri 4.0 (Purnawan, Khisni \& Witasari, 2019); dan Amin Purnawan yang berfokus pada rekonstruksi kebijakan perpajakan berdasarkan nilai keadilan untuk mendorong daya saing industri di era global (Purnawan, 2018).

Atas penelitian sebelumnya, terdapat perbedaan fokus penelitian yang akan dilakukan saat ini dengan penelitian yang sudah ada. Walaupun sama-sama mengambil tema tentang Pajak 
Pengahasilan, namun penelitian ini lebih menekankan pada kebijakan penurunan tarif PPh final bagi UMKM dan pengurah terhadap kepatuhan UMKM sebagai Wajib Pajak di KPP Pratama Semarang Barat, sehingga membuat pembahasan mengenai hal ini menjadi hal yang selalu penting dan aktual untuk dilakukan pengkajian.

\section{B. METODE PENELITIAN}

Metode penelitian yang digunakan pada penelitian ini adalah metode penelitian kualitatif. Penelitian ini akan dilakukan di Kantor Pelayanan Pajak (KPP) Pratama Semarang Barat. Metode pendekatan yang digunakan adalah pendeketan yuridis empiris (sosiologis). Penelitian ini menggunakan data primer yang diperoleh secara langsung pada objek penelitian dan data sekunder yang berhubungan dengan perunahan tariff PPh final bagi UMKM selaku Wajib Pajak di KPP Pratama Semarang Barat.

\section{PEMBAHASAN}

1. Kebijakan Penurunan Tarif Pajak Penghasilan (PPh) Final Bagi Pelaku UMKM

a. Kebijakan Pajak PPh Final Sebesar $1 \%$ Bagi Pelaku UMKM

Melihat besarnya potensi penerimaan pajak dari UMKM yang belum tergali secara maksimal, maka sejak tahun 2012 pemerintah mulai mempersiapkan sebuah peraturan pemerintah yang mengatur perusahaan atau dalam hal ini adalah wajib pajak dengan penghasilan atau peredaran bruto tertentu (Endrianto, 2015). Juni 2013, pemerintah mengundangkan Peraturan Pemerintah yang menerapkan pajak $1 \%$ bagi UMKM. Peraturan ini dituangkan dalam Peraturan Pemerintah Nomor 46 Tahun 2013 tentang Pajak Penghasilan Atas Penghasilan Dari Usaha Yang Diterima Atau Diperoleh Wajib Pajak Yang Memiliki Peredaran Bruto Tertentu (PP No. 46 tahun 2013). PP No. 46 tahun 2013 yang menerapkan pajak 1\% bagi UMKM dinilai sebagai bentuk penindasan pemerintah dengan kedok legislasi penyederhanaan PPh terhadap pengusaha kecil (Aneswari, Darmayasa \& Yusdita, 2015).

Adapun materi pokok yang diatur dalam PP No. 46 tahun 2013 ini mengenai pengenaan PPh yang bersifat final dan penetapan besaran tarif pajak terhadap penghasilan dari usaha yang diterima atau diperoleh Wajib Pajak yang memiliki peredaran bruto tertentu dalam hal ini adalah UMKM. Pengenaan PPh yang bersifat final tersebut ditetapkan dengan berdasarkan pada pertimbangan perlunya kesederhanaan dalam pemungutan pajak, berkurangnya beban administrasi baik bagi Wajib Pajak maupun Direktorat Jenderal Pajak (DJP), serta memperhatikan perkembangan ekonomi dan moneter. Tujuan pengaturan ini adalah untuk memberikan kemudahan kepada UMKM sebagai Wajib Pajak, untuk melakukan penghitungan, penyetoran, dan pelaporan PPh yang terutang.

Subjek pajak dari PP 46 tahun 2013 ini diatur dalam Pasal 2 yang menyebutkan bahwa atas penghasilan dari usaha yang diterima atau diperoleh Wajib Pajak yang memiliki peredaran bruto tertentu,dikenai Pajak Penghasilan yang bersifat 
final. Wajib Pajak yang memiliki peredaran bruto tertentu sebagaimanadimaksud pada ayat (1) adalah Wajib Pajak yang memenuhi kriteria bahwa wajib Pajak orang pribadi atau Wajib Pajak badan tidak termasuk bentuk usaha tetap dan menerima penghasilan dari usaha, tidak termasuk penghasilan dari jasa sehubungan dengan pekerjaan bebas, dengan peredaran bruto tidak melebihi Rp. 4.800.000.000, (empat miliar delapan ratus juta rupiah) dalam 1 (satu) Tahun Pajak.

Tidak termasuk Wajib Pajak orang pribadi sebagaimana dimaksud pada ayat (2) adalah Wajib Pajak orang pribadi yang melakukan kegiatan usaha perdagangan dan/atau jasa yang dalam usahanya yang menggunakan sarana atau prasarana yang dapat dibongkar pasang,baik yang menetap maupun tidak menetap dan menggunakan sebagian atau seluruh tempat untuk kepentingan umum yang tidak diperuntukkan bagi tempat usaha atau berjualan. Tidak termasuk Wajib Pajak badan sebagaimana dimaksud pada ayat (2) adalah wajib Pajak badan yang belum beroperasi secara komersial dan wajib Pajak badan yang dalam jangka waktu 1 (satu) tahunsetelah beroperasi secara komersial memperoleh peredaran bruto melebihi Rp4.800.000.000.

Seperti disebutkan sebelumnya, ketentuan Wajib Pajak yang memiliki peredaran bruto tertentu dalam hal ini adalah UMKM (Maharatih, 2019). UMKM merupakan bentuk usaha yang mampu menyerap banyak tenaga kerja karena pada umumnya UMKM berupa usaha padat karya.
Kemudian pajak penghasilan atau PPh yang dimaksud dalam PP 46 tahun 2013 dikenakan pada penghasilan Rp. 4,800.000.000 dalam satu tahun pajak dan pajak yang harus dibayar UMKM adalah 1\% dari omzet tersebut (Aneswari, Darmayasa \& Yusdita, 2015).

Kemudian pengaturan besaran pengenaan tarif pajak bagi UMKM pada PP 46 tahun 2013 ini diatur dalam Pasal 3, yang menyebutkan bahwa besarnya tarif Pajak Penghasilan yang bersifat final sebagaimana dimaksud dalam Pasal 2 adalah 1\% (satu persen). Pengenaan Pajak Penghasilan sebagaimana dimaksud pada ayat (1) didasarkan pada peredaran bruto dari usaha dalam 1 (satu) tahun dari Tahun Pajak terakhir sebelum Tahun Pajak yang bersangkutan.

Apabila peredaran bruto kumulatif Wajib Pajak pada suatu bulan telah melebihi jumlah $\mathrm{Rp}$. 4.800.000.000 dalam suatu Tahun Pajak, Wajib Pajak tetap dikenai tarif Pajak Penghasilan yang telah ditentukan berdasarkan ketentuan sebagaimana dimaksud pada ayat (1) sampai dengan akhir Tahun Pajak yang bersangkutan. Dalam hal peredaran bruto Wajib Pajak telah melebihi jumlah Rp. 4.800.000.000 pada suatu Tahun Pajak, atas penghasilan yang diterima atau diperoleh Wajib Pajak pada Tahun Pajak berikutnya dikenai tarif Pajak Penghasilan berdasarkan ketentuan Undang-Undang Pajak Penghasilan.

PP No. 46 tahun 2013 ini mengundang banyak protes dikarenakan sejak pajak $1 \%$ ini diterapkan bukan dari laba namun dari omzet. Setiap UMKM 
Jurnal Pembangunan Hukum Indonesia

Volume 2, Nomor 2, Tahun 2020
Program Studi Magister Ilmu Hukum Fakultas Hukum Universitas Diponegoro yang ada pastinya memiliki omzet, namun belum tentu setiap bulan akan memiliki laba yang cukup baik terlebih lagi setelah dibebankan pajak sebesar 1\% (Aneswari, Darmayasa \& Yusdita, 2015). Apabila dianalisis dengan pisau analisis Teori Keadilan yang dikemukakan oleh Gustav Radbruch, maka PPh final 1\% yang dikenakan kepada UMKM kurang sesuai dengan nilai-nilai keadilan itu sendiri. Sebagai komponen penting di Indonesia UMKM merupakan objek pajak potensial bagi pemerintah mengingat perkembangan UMKM yang begitu pesat. UMKM memiliki peran besar dalam pertumbuhan perekonomian di Indonesia.

Banyak kebijakan yang dilakukan pemerintah untuk meningkatkan kinerja perpajakan, salah satunya adalah pemberlakukan pajak $1 \%$ dari omzet UMKM yang dilegitimasi melalui PP No. 46 tahun 2013, selain itu PPh 1\% ini merupakan bentuk penyederhanaan dalam membayar PPh, terutama bagi UMKM yang tidak familiar dengan pembukuan (Aneswari, Darmayasa \& Yusdita, 2015).

Konsep kesederhanaan yang dianut dalam PP No. 46 tahun 2013 merupakan pengecualian dari prinsip-prinsip hukum undang-undang perpajakan. Prinsip utama UU Pajak Penghasilan adalah "penghasilan", dengan alasan kesederhanaan bagi wajib pajak yang peredaraan usahanya setahun tidak lebih dari Rp. 4,8 miliar yang dalam sosialisasinya berlaku bagi UMKM, pajak penghasilan dikenakan berdasarkan peredaraan usaha. Permasalahan ini apabila dianalisis melalui Teori Kepastian Hukum yang dikemukakan oleh Gustav Radbruch telah menimbulkan sebuah ketidakpastian hukum yang seharusnya dianut oleh negara hukum. Alasan demi kesederhanaan telah menimbulkan banyak pasalpasal dalam UU Pajak Penghasilan yang dilanggar oleh PP No. 46 tahun 2013. Pengambilan kebijakan perpajakan harus tetap mempertimbangkan asas kepastian hukum baik di bidang perpajakan maupun di bidang lainnya. PP No. 46 Tahun 2013 juga telah melanggar prinsip lex superior derogat legi inferiori, bahwa peraturan perundang-undangan yang lebih rendah tidak boleh bertentangan berngan peraturan perundang-undangan yang lebih tinggi.

Pro dan kontra mengenai PP No. 46 tahun 2013 sebenarnya telah lama berkembang. Perihal kesamarataan ialah kontra yang berulang kali diungkit karena PPh menurut PP ini tergolong pajak final, pajak bersifat final dapat diartikan bahwa tidak melihat apakah hasil akhir dari usaham UMKM sebagai wajib pajak laba atau rugi. Selama UMKM mempunyai omset penghasilan maka UMKM sebagai wajib pajak harus membayar pajak. Pada saat akhir tahun, penghasilan bersih satu tahun kurang dari Penghasilan Tidak Kena Pajak (PTKP), namun wajib pajak yang tergolong UMKM tetap harus membayar. Tidak aneh jika muncul keberatan dari Wajib Pajak khususnya UMKM terkait tariff pajak penghasilan/PPh 1\% dari omset penghasilan.

\section{b. Kebijakan Penurunan PPh Final Sebesar 0,5\% Bagi Pelaku UMKM}

Juni 2018 Presiden Joko Widodo meluncurkan tarif PPh final yang baru bagi pelaku UMKM di hadapan ribuan pelaku UMKM di Surabaya dan Bali 
Jurnal Pembangunan Hukum Indonesia

Volume 2, Nomor 2, Tahun 2020
Program Studi Magister Ilmu Hukum Fakultas Hukum Universitas Diponegoro
(Sari, 2018). Peraturan Pemerintah ini diterbitkan sebagai masa pembelajaran bagi Wajib Pajak yang memiliki peredaran bruto tertentu untuk dapat menyelenggarakan pembukuan sebelum dikenai PPh final. Sehingga Wajib Pajak akan lebih mudah dalam melaksanakan dan memenuhi kewajiban perpajakan. Alasan diterbitkannya Peraturan Pemerintah ini untuk mendorong masyarakat agar lebih berperan serta dalam kegiatan ekonomi formal, dengan cara memberikan kemudahan jangka waktu tertentu kepada Wajib Pajak yang memiliki peredaran bruto tertentu dalam melaksanakan kewajiban perpajakan (Purnawan, Khisni \& Witasari, 2019).

Di samping itu, dikeluarkannya Peraturan Pemerintah ini diharapkan memberikan keadilan kepada Wajib Pajak yang memiliki peredaran bruto tertentu yang telah mampu melakukan pembukuan, sehingga Wajib Pajak dapat memilih untuk dikenai PPh berdasarkan tarif umum UU Pajak Penghasilan (Maharatih, 2019).

Penetapan besaran tarif UMKM yang baru tertuang dalam Peraturan Pemerintah Nomor 23 Tahun 2018 tentang Pajak Penghasilan atas Penghasilan Usaha Yang Diterima atau Diperoleh Wajib Pajak yang Memiliki Peredaran Bruto Tertentu (PP No. 23 Tahun 2018). Peraturan tersebut menggantikan peraturan sebelumnya, yaitu PP No. 46 tahun 2013 dengan tarif PPh final UMKM sebesar $1 \%$ menjadi $0,5 \%$.

Pengaturan besaran pengenaan tarif pajak bagi UMKM pada PP 23 tahun 2018 ini diatur dalam Pasal 2, yang menyebutkan: 1). Atas penghasilan dari usaha yang diterima atau diperolehWajib Pajak dalam negeri yang memiliki peredaran brutotertentu, dikenai Pajak Penghasilan yang bersifat finaldalam jangka waktu tertentu; dan 2). Tarif pajak penghasilan yang bersifat finan sebagaiman dimaksud pada ayat (1) sebesar 0,5\%.

Kemudian pengaturan subjek pajak dari PP 23 tahun 2018 ini diatur dalam Pasal 3 ayat (1) yang menyebutkan Wajib Pajak yang memiliki peredaran bruto tertentu yangdikenai Pajak Penghasilan final sebagaimana dimaksuddalam Pasal 2 ayat (I) merupakan: 1). Wajib Pajak orang pribadi; dan 2). Wajib Pajak badan berbentuk koperasi, persekutuan komanditer (CV), firma, atau perseroan terbatas, yang menerima atau memperoleh penghasilan dengan peredaran bruto tidak melebihi $\mathrm{Rp}$. 4.800.000.000 dalam satu tahun pajak.

Kebijakan penurunan PPh final bagi pelaku UMKM merupakan salah satu fasilitas fiskal yang diberikan oleh pemerintah kepada pelaku UMKM untuk mendorong potensi/aktivitas sektor UMKM namun juga akan mengurangi potensi penerimaan pajak pada jangka pendek (Sari, 2018). Pengenaan tarif pajak final lama bagi UMKM sebesar 1\% dinilai memberatkan pelaku UMKM dan sering dikeluhkan oleh pelaku UMKM. Kebijakan penurunan PPh bagi UMKM memberikan keringanan pajak bagi pelaku UMKM dengan potongan pajak sebesar 0,5\%. Dari sisi pelaku usaha, penurunan tarif baru diharapkan menstimulasi munculnya pelaku UMKM baru untuk berkembang dan memberikan ruang finansial atau kesempatan berusaha dengan berkurangnya beban 
Jurnal Pembangunan Hukum Indonesia

Volume 2, Nomor 2, Tahun 2020
Program Studi Magister Ilmu Hukum Fakultas Hukum Universitas Diponegoro

biaya UMKM untuk dapat digunakan dalam Firma; dan b). 3 tahun pajak bagi Wajib Pajak Badan menumbuhkan usaha.

Terhadap kebijakan perubahan pengenaan berbentuk Perseroan Terbatas atau PT.

Selanjutnya Pasal 5 ayat (2) PP No. 23 Tahun tarif PPh Final bagi UMKM tersebut, ada beberapa hal lain yang juga perlu mendapat perhatian khusus, yang dapat dilihat pada bagan berikut:

a) Tarif PPh Final Bersifat Opsional

Ketentuan PP No. 23 Tahun 2018 ini bersifat opsional karena Wajib Pajak Badan dapat memilih untuk mengikuti skema tarif PPh Final 0,5\% ataupun menggunakan skema normal sebagaimana diatur pada Pasal 17 UU tentang Pajak Penghasilan. Sifat opsional ini dapat memberikan keuntungan bagi Wajib Pajak Badan, terutama bagi Badan yang telah melakukan pembukuan dengan baik (Lutfi, 2020). Hal ini dikarenakan Wajib Pajak Badan dapat memilih untuk dikenai Pajak Penghasilan berdasarkan skema tarif normal yang diatur pada Pasal 17 UU Pajak Penghasilan. Dengan skema ini, perhitungan tarif PPh akan mengacu pada lapisan penghasilan kena pajak. Selain itu, Wajib Pajak juga terbebas dari PPh apabila mengalami kerugian fiscal (Lutfi, 2020).

b) Pengenaan Tarif PPh Final 0,5\% Memiliki Batas Waktu

Kebijakan tentang penurunan PPh Final 0,5\% memilikigrace period atau batas waktu. Ini merupakan salah satu hal yang membedakan dengan peraturan sebelumnya. Adapun rinciannya sesuai Pasal 5 ayat (1) PP No. 23 Tahun 2018 adalah sebagai berikut: a). 4 tahun pajak bagi Wajib Pajak Badan berbentuk koperasi, Persekutuan Komanditer atau yang lebih dikenal dengan CV , atau

2018 menyebutkan jangka waktu di atas terhitung sejak tahun pajak Wajib Pajak terdaftar, bagi Wajib Pajak yang terdaftar sejak berlakunya PP No. 23 Tahun 2018, atau tahun Pajak berlakunya PP No. 23 Tahun 2018, bagi Wajib Pajak yang telah terdaftar sebelum berlakunya PP No. 23 Tahun 2018 ini. Setelah batas waktu tersebut berakhir, Wajib Pajak akan kembali menggunakan skema tarif normal sebagaimana diatur dalam Pasal 17 UU Pajak Penghasilan. Hal ini bertujuan untuk mendorong Wajib Pajak agar menyelenggarakan pembukuan dan pengembangan usaha (Lutfi, 2020).

c) Berpenghasilan di Bawah 4,8 Miliar

Ambang batas penghasilan Wajib Pajak yang dikenai PPh final dalam PP Nomor 23 Tahun 2018 tidak berubah, yakni senilai Rp. 4.800 .000 .000 (Empat Miliar Delapan Ratus Juta Rupiah) dalam satu tahun pajak. Ketentuan besaran ambang batas penghasilan ini di atur dalam Pasal 3 ayat (1) PP Nomor 23 Tahun 2018.

d) Terdapat Wajib Pajak Yang Tidak Dapat Memanfaatkan PPh Final 0,5\%

Berdasarkan Pasal 3 ayat (1) kriteria dan sasaran Wajib Pajak PPh final pada PP No. 23 Tahun 2018 yang dapat memanfaatkan tarif final adalah Wajib Pajak Orang Pribadi dan Wajib Pajak Badan yang berbentuk Koperasi, Persekutuan Komanditer atau CV, Firma atau Perseroan Terbatas (PT) yang menerima atau memperoleh penghasilan 
Jurnal Pembangunan Hukum Indonesia

Volume 2, Nomor 2, Tahun 2020
Program Studi Magister Ilmu Hukum Fakultas Hukum Universitas Diponegoro dari usaha dengan peredaran bruto bruto di bawah Rp. 4.800.000.000.

e) Wajib Pajak Perlu Mengajukan Diri Jika Ingin Menggunakan Skema Tarif Normal

Wajib Pajak yang tidak ingin berstatus sebagai Wajib Pajak PPh Final 0,5\%, harus terlebih dahulu mengajukan permohonan tertulis kepada Ditjen Pajak. Selanjutnya Ditjen Pajak akan memberikan surat keterangan yang menyatakan bahwa Anda merupakan Wajib Pajak yang dikenai skema tarif normal sesuai dengan Pasal 17 UU Pajak Penghasilan (Lutfi, 2020). Bagi Wajib Pajak yang sudah memilih untuk dikenai PPh dengan skema tarif normal tidak dapat memilih untuk dikenai skema PPh Final $0,5 \%$.

\section{Pengaruh Perubahan PPh Final Terhadap} Tingkat Kepatuhan Pelaku UMKM Sebagai Wajib Pajak Di Kantor Pelayanan Pajak

\section{Semarang Barat}

Kepatuhan Wajib Pajak dapat dipengaruhi oleh dua jenis faktor yaitu faktor internal dan faktor eksternal. Faktor internal merupakan faktor yang berasal dari diri Wajib Pajak sendiri dan berhubungan dengan karakteristik individu yang menjadi pemicu dalam menjalankan kewajiban perpajakannya (Jotopurnomo \& Mangoting, 2013). Berbeda dengan faktor internal, faktor eksternal adalah faktor yang berasal dari luar diri Wajib Pajak, seperti kebijakan terkait pajak, situasi dan lingkungan di sekitar Wajib Pajak.

Kepatuhan Wajib Pajak juga bisa di ukur dari pertumbuhan penerimaan atau pendapatan pajak sebagai fungsi budgetair dalam pemasukan uang pada kas negara (Lutfi, 2020). Pertumbuhan pendapatan pajak sendiri dipengaruhi adanya kesadaran Wajib Pajak dalam melakukan pembayaran pajak. Sehingga kesadaran Wajib Pajak mengenai perpajakan amatlah diperlukan guna meningkatkan kepatuhan Wajib Pajak (Jotopurnomo \& Mangoting, 2013). Selain kesadaran sebagai faktor internal tersebut, hadirnya kebijakan penurunan tarif PPh final sebesar 0,5\% bagi UMKM juga menjadi faktor dari tingkat kepatuhan Wajib Pajak (Lutfi, 2020).

Sistem self assessment yang berlaku di Indonesia memberikan Wajib Pajak kepercayaan penuh untuk melaksanakan kewajiban pembayaran pajak dengan menghitung, membayar, dan melaporkan pajaknya sendiri (Hasibuan, 2019). Adanya penurunan tarif PPh final bagi UMKM melalui PP No. 23 Tahun 2018 merupakan salah satu faktor yang mendukung tingkat kepatuhan UMKM dalam melaksanakan kewajiban pajaknya karena wajib pajak dapat melaksanakan dan memenuhi kewajiban pajaknya dengan cara mudah dan sederhana.

Sebagaimana data yang diperoleh dari objek penelitian, adanya kebijakan penurunan tarif PPh final dari 1\% menjadi 0,5\% melalui PP No. 23 Tahun 2018 ini juga mempengaruhi penerimaan pajak dari UMKM itu sendiri (Purnawan, Khisni \& Witasari, 2019). Data yang menjadi sampel penerimaan pajak adalah 7 (tujuh) KLU (Klasifikasi Lapangan Usaha) yang terdapat di KPP Pratama Semarang Barat 
Jurnal Pembangunan Hukum Indonesia

Volume 2, Nomor 2, Tahun 2020
Program Studi Magister Ilmu Hukum

Fakultas Hukum Universitas Diponegoro sebagai objek penelitian. Adapun data penerimaan pajak yang diterima KPP Pratama Semarang Barat dapat dilihat pada Tabel 1.

Berdasarkan data yang di peroleh, menunjukan masih terdapat UMKM atau Wajib Pajak yang tidak patuh melaksanakan kewajibannya dalam membayar pajak. Atas dasar penerimaan pajak Kantor Pelayanan Pajak Pratama Semarang Barat, terdapat beberapa KLU yang tidak melaksanakan kewajiban pajaknya, hal ini dikarenakan masih banyak Wajib Pajak khususnya UMKM di wilayah Kantor Pelayanan Pajak Pratama Semarang Barat yang belum mengetahui Peraturan Pemerintah tersebut

Sebagai contoh dapat dilihat pada penerimaan pajak dari Wajib Pajak kategori KLU bidang otomotif dan KLU bidang kerajinan tangan mengalami penurunan pada tahun 2019, dimana di tahun menggunakan skema pembayaran pajak dengan besaran 1\% yang masih menggunakan PP No. 46 tahun 2013. Adanya kemudahan bagi pelaku UMKM dengan adanya penurunan PPh final sebesar 0,5\% maka seharusnya penerimaan pajak pada tahun 2019 untuk KLU ini kurang lebih sebesar Rp.10.904.410.677, namun di tahun 2019 penerimaan pajak dari KLU ini hanya sebasar Rp.2.814.353.727. Dapat dikatakan bahwa masih terdapat pelaku usaha UMKM yang tidak melaksanakan kewajiban pajaknya atau dengan kata lain adanya penuggakan pembayaran pajak oleh UMKM selaku Wajib Pajak (Lutfi, 2020).

Kemudian penerimaan pajak KLU Bidang Kerajinan Tangan. Ditahun 2018, penerimaan pajak KLU ini adalah sebesar Rp. 671.949.911 dengan menggunakan skema pembayaran pajak sebesar $1 \%$, maka seharusnya penerimaan pajak pada tahun

Tabel 1.

\begin{tabular}{r|c|r|r|r|}
\hline No. & Jenis KLU & \multicolumn{1}{c|}{2018} & \multicolumn{1}{c|}{2019} & \multicolumn{1}{c|}{ Seharusnya } \\
\hline 1 & Bidang Kuliner & $26,519,414,365$ & $49,351,641,953$ & $13,259,707,183$ \\
\hline 2 & Bidang Otomotif & $21,808,821,353$ & $2,814,353,727$ & $10,904,410,677$ \\
\hline 3 & Bidang Fashion & $90,629,201,443$ & $78,962,905,132$ & $45,314,600,722$ \\
\hline 4 & $\begin{array}{c}\text { Bidang Pertanian, } \\
\text { Perikanan. dan }\end{array}$ & $7,229,305,596$ & $9,100,065,552$ & $3,614,652,798$ \\
\hline 5 & $\begin{array}{c}\text { Bidang Perdagangan, } \\
\text { Hotel dan Restoran }\end{array}$ & $755,219,637,279$ & $746,160,830,775$ & $377,609,818,640$ \\
\hline 6 & Bidang Kerainan & $671,949,911$ & $233,315,176$ & $335,974,956$ \\
\hline 7 & $\begin{array}{c}\text { Bidang Industri } \\
\text { Penqolahan }\end{array}$ & $301,080,128,626$ & $362,931,097,444$ & $150,540,064,313$ \\
\hline
\end{tabular}

sebelumnya penerimaan pajak masing-masing KLU 2019 untuk KLU ini kurang lebih sebesar tersebut lebih besar. Padahal, adanya kebijakan Rp.335.974,955, namun di tahun 2019 penerimaan penurun PPh final dari $1 \%$ menjadi $0,5 \%$ menjadi pajak dari KLU ini hanya sebasar Rp.233.316.176. suatu kemudahan bagi pelaku UMKM dalam Samahalnya dengan KLU bidang otomotif melaksanakan kewajibannya (Lutfi, 2020).

sebelumnya, dapat dikatakan bahwa masih terdapat

Penerimaan pajak KLU bidang otomotif di tahun 2018 sebesar Rp.21.808.821.353 dengan pelaku usaha UMKM yang tidak melaksanakan kewajiban pajaknya atau dengan kata lain adanya 
Jurnal Pembangunan Hukum Indonesia

Volume 2, Nomor 2, Tahun 2020
Program Studi Magister Ilmu Hukum Fakultas Hukum Universitas Diponegoro penuggakan pembayaran pajak oleh UMKM selaku Wajib Pajak (Lutfi, 2020).

Berbeda dengan KLU lainnya, dengan adanya kebijakan penurunan PPh final sebasar $0,5 \%$ bagi UMKM menunjukan adanya peningkatan kepatuhan Wajib Pajak dalam hal ini adalah UMKM. Misalnya KLU bidang kuliner, KLU bidang fashion, KLU bidnag pertanian, perikanan dan peternakan, KLU bidang perdagangan, hotel dan Restoran, dan KLU bidang industri pengolahan. Adapun rincian kenaikan penerimaan pajak di masing-masing KLU ini dapat dilihat pada Tabel 2 .

Berdasarkan data pada Tabel 2 tersebut, menunjukan bahwa adanya kebijakan penurunan PPh final sebesar 0,5\% bagi UMKM mengakibatkan banyak dari pelaku usaha UMKM yang tingkat keatuhannya dalam melaksanakan kewajiban masih melakukan penunggakan kewajiban pajaknya. Hal ini dikarenakan masih banyak Wajib Pajak khususnya UMKM di wilayah KPP Pratama Semarang Barat yang belum mengetahui Peraturan Pemerintah tersebut (Lutfi, 2020).

Upaya yang dilakukan KPP Semarang Barat dalam rangka mengatasi kendala tersebut adalah dengan melakukan sosialisasi edukasi kepada wajib pajak UMKM. Sosialisasi yang dilakukan oleh Kantor Pelayanan Pajak Pratama Semarang Barat, merupakan upaya yang dilakukan dengan berbagai program dalam memberikan informasi terkait segala kebijakan yang terkait dengan perpajakan kepada masyarakat pada umumnya dan Wajib Pajak khususnya, baik orang pribadi maupun badan usaha. Program-progaram yang telah dilakukan oleh Kantor Pelayanan Pajak Pratama Semarang Barat berkaitan

Tabel 2.

\begin{tabular}{c|l|c|c|c|}
\hline No. & \multicolumn{1}{|c|}{ Jenis KLU } & $\begin{array}{c}\text { Sebelumnya 2018 } \\
(1 \%)\end{array}$ & $\begin{array}{c}\text { Seharusnya } 2019 \\
(0,5 \%)\end{array}$ & Realisasi \\
\hline 1 & Bidang Kuliner & $26,519,414,365$ & $13,259,707,183$ & $49,351,641,953$ \\
\hline 2 & Bidang Fashion & $90,629,201,443$ & $45,314,600,722$ & $78,962,905,132$ \\
\hline 3 & $\begin{array}{l}\text { Bidang Pertanian, } \\
\text { Perikanan, Dan Peternakan }\end{array}$ & $7,229,305,596$ & $3,614,652,798$ & $9,100,065,552$ \\
\hline 4 & $\begin{array}{l}\text { Bidang Perdagangan, } \\
\text { Hotel, Dan Restoran }\end{array}$ & $755,219,637,279$ & $377,609,818,640$ & $746,160,830,775$ \\
\hline 5 & $\begin{array}{l}\text { Bidang Industri } \\
\text { Pengolahan }\end{array}$ & $301,080,128,626$ & $150,540,064,313$ & $362,931,097,444$ \\
\hline
\end{tabular}

pajaknya meningkat (Lutfi, 2020).

Atas dasar peningkatan penerimaan pajak dari UMKM sebagai Wajib Pajak dibeberapa KLU, mengindikasikan bahwasanya kebijakan penurunan tarif PPh final sebesar 0,5\% teruntuk UMKM melalui PP No. 23 Tahun 2018 merupakan faktor pendukung meningkatnya kepatuhan pelaku usaha UMKM sebagai Wajib Pajak, walaupun tidak sedikit yang dengan sosialisasi pajak dalam rangka meningktakan kepatuhan Wajib Pajak anatara lain, mengadakan penyuluhan-penyuluhan terkait adanya kebijakan penurunan PPh final sebesar $0,5 \%$ bagi pelaku usaha UMKM sebagai Wajib Pajak yang memiliki kewajiban dalam membayar pajak, memasang spanduk yang berkaitan dengan pajak secara umum, dan kebijakan penurunan tarif pajak yang di atur 
Jurnal Pembangunan Hukum Indonesia

Volume 2, Nomor 2, Tahun 2020
Program Studi Magister Ilmu Hukum Fakultas Hukum Universitas Diponegoro dalam PP No. 23 Tahun 2018 khususnya, dan memberikan penghargaan kepada Wajib Pajak yang patuh atas kewajiban pajaknya, dalam rangka memicu peningkatkan ketaatan Wajib Pajak.

KPP Semarang Barat selain melakukan sosialisasi juga memberikan edukasi terhadap Wajib Pajak usaha baru yang berstatus UMKM. Pihak Kantor Pelayanan Pajak Pratama Semarang Barat melakukan wawancara untuk mengdapatkan informasi terkait usaha, omset atau penghasilan, apabila telah memenuhi syarat, maka akan menghimbau agar pelaku usaha UMKM tersebut memiliki NPWP. Edukasi ini juga bertujuan untuk melatih Wajib Pajak dalam melaksanakan kewajiban pajak. Secara umum dapat dikatakan edukasi, dimaksudkan untuk meningkatkan pengetahuan Wajib Pajak tentang pajak yang baik. pengetahuan adalah hasil kerja fikir yang merubah tidak tahu menjadi tahu, dan menghilangkan keraguan terhadap sesuatu hal/perkara. Pengetahuan Wajib Pajak disini adalah meliputi pengetahuan peraturan atau kebijakan penurunan PPh final sebesar 1\% menjadi 0,5\% bagi pelaku usaha UMKM sebagai Wajib Pajak.

\section{SIMPULAN}

Kebijakan perubahan tarif Pajak Penghasilan (PPh) Final terhadap pelaku UMKM di Kantor Pelayanan Pajak Pratama Semarang Barat terdapat dalam Peraturan Pemerintah Nomor 23 Tahun 2018 tentang Pajak Penghasilan atas Penghasilan Usaha Yang Diterima atau Diperoleh Wajib Pajak Yang Memiliki Peredaran Bruto Tertentu. Beberapa hal yang mendapat perhatian khusus, yaitu tarif PPh
Final Bersifat Opsional, pengenaan tarif PPh Final 0,5\% Memiliki Batas Waktu, Perpenghasilan di Bawah 4,8 Miliar, terdapat wajib pajak yang tidak dapat memanfaatkan PPh Final 0,5\%, dan wajib pajak perlu mengajukan diri jika ingin menggunakan Skema tarif normal.

Pengaruh kebijakan perubahan tarif Pajak Penghasilan (PPh) Final terhadap tingkat kepatuhan Wajib Pajak pelaku UMKM di Kota Semarang Barat, bahwa kebijakan penurunan tarif PPh final sebesar $0,5 \%$ merupakan faktor pendukung meningkatnya kepatuhan pelaku usaha UMKM sebagai Wajib Pajak, walaupun tidak sedikit yang masih melakukan penunggakan kewajiban pajaknya, hal ini dikarenakan masih banyak Wajib Pajak khususnya UMKM di wilayah Kantor Pelayanan Pajak Pratama Semarang Barat yang belum mengetahui Peraturan Pemerintah tersebut. Upaya yang dilakukan KPP Semarang Barat dalam rangka mengatasi kendala tersebut adalah dengan melakukan sosialisasi dan edukasi kepada wajib pajak UMKM mengenai kebijakan penurunan tarif PPh final sebesar 0,5\% teruntuk UMKM sebagaimana diatur PP No. 23 Tahun 2018.

\section{Kepada Kantor Pelayanan Pajak Semarang} Barat diharapkan untuk mengoptimalkan upayaupaya dalam meningkatkan kepatuhan Wajib Pajak, dan meginformasikan kebijakan penurunan PPh final 0,5\% kepada pelaku usaha UMKM selaku Wajib Pajak. Dengan optimalisasi upaya-upaya untuk meningkatkan kepatuhan wajib pajak diharapkan dapat meningkatkan pendapatan negara dari sektor 
pajak yang akan digunakan untuk pembiayaan pembangunan nasional dalam rangka mewujudkan kesejahteraan bagi masyarakat.

\section{DAFTAR PUSTAKA}

\section{BUKU}

Bohari. (2006). Pengantar Hukum Pajak. Jakarta: PT

Raja Grafindo Persada.

Siahaan, Marihot P. (2010). Pajak Daerah dan

Retribusi Daerah.Jakarta: PT Rajagrafindo Persada.

\section{J URNAL / ARTIKEL ILMIAH LAINNYA}

Ananda, Amin Dwi., \& Susilowati, Dwi. (2015).

Pengembangan Usaha Mikro Kecil dan Menengah (UMKM) Berbasis Industri Kreatif di Kota Malang. J urnal IImu Ekonomi JIE, Vol.1, (No.1), pp. 120-142.

Aneswari, Yuyung Rizka., Darmayasa, I Nyoman., \& Yusdita, Elana Era. (2015). Perspektif Kritis Penerapan Penghasilan 1\% Pada UMKM. Simposium Nasional Perpajakan, Vol.5, pp. 122.

Disemadi, Hari Sutra., \& Roisah, Kholis. (2019). Kebijakan Model Bisnis Bank Wakaf Mikro Sebagai Solusi Pemberdayaan Ekonomi Masyarakat. Law Reform, Vol.15, (No.2), pp. 177-194.

Endrianto, W. (2015). Prinsip Keadilan Dalam Pajak Atas UMKM. Binus Business Review, Vol.6, (No.2), pp. 298-308.
Hasibuan, Batara M. (2019). Pemberian Insentif Pajak Penghasilan Di Bidang Penanaman Modal Dalam Perspektif Teori Hukum. Nagari Law Review, Vol.3, (No.1), pp. 104-119.

Ispriyarso, B. (2015). Sandera Pajak Sebagai Alat Paksa Dalam Penagihan Utang Pajak. Masalah-Masalah Hukum, Vol.44, (No.1), pp. 69-77.

Jotopurnomo, Cindy., \& Mangoting, Yenni. (2013). Pengaruh Kesadaran Wajib Pajak, Kualitas Pelayanan Fiskus, Sanksi Perpajakan, Lingkungan Wajib Pajak Berada Terhadap Kepatuhan Wajib Pajak Orang Pribadi Di Surabaya. Tax \& Accounting Review, Vol.1 (No.1), pp. 49-54.

Kumaratih, Cinantya., Ispriyarso, Budi., \& Sa'adah, Nabitatus. (2018). Pemungutan Pajak Atas Parkir (Kajian Perbandingan Antara Pajak Atas Parkir dan Pajak Penghasilan Atas Pengeloaan Parkir). Skripsi: Universitas Diponegoro.

Kusuma, Agus I. (2016). Pengampunan Pajak (Tax Amnesty) Sebagai Upaya Optimalisasi Fungsi Pajak. J urnal Inovasi, Vol.12, (No.2), pp. 270280.

Maharatih, Ni W. (2019). Studi Kritis Pengenaan Pajak Penghasilan Final Bagi Usaha Mikro Kecil Menengah. Jurnal Magister Hukum Udayana (Udayana Master Law Journal), Vol.8, (No.1), pp. 105-115.

Mulyadi, M. Budi. (2018). Pengaruh Kualitas Pelayanan Perizinan Terpadu dalam 
Jurnal Pembangunan Hukum Indonesia

Volume 2, Nomor 2, Tahun 2020
Program Studi Magister Ilmu Hukum Fakultas Hukum Universitas Diponegoro
Meningkatkan Investasi dan Pertumbuhan

UMKM. J urnal Hukum Mimbar J ustitia, Vol.4, (No.1), pp. 112-127.

Purnawan, A. (2011). Rekonstruksi Sistem

Pemungutan Pajak Penghasilan (PPh) Badan

Berbasis Nilai Keadilan. Jurnal Dinamika

Hukum, Vol. 11, pp. 36-46.

Purnawan, A. (2018). Taxing Policy Reconstruction

Based on Justice Value to Encourage

Industrial Competitiveness in the Global Era. International Journal of Law Reconstruction, Vol.1, (No.1), pp. 161-176.

Purnawan, Amin., \& Adillah, Siti Ummu. (2014).

Kebijakan Pajak Daerah Berbasis Keadilan untuk Mendorong Pertumbuhan Usaha Kecil Menengah (UKM) di Jawa Tengah. Jurnal Pembaharuan Hukum, Vol.1, (No.3), pp. 241251.

Purnawan, Amin., Khisni, Ahmad., \& Witasari, Aryani. (2019). Politics of Law of Imposing Income Tax (PPh) Based on Micro, Small and Medium Enterprises (MSMEs) with Justice Value Base to Increase Voluntary Tax Compliance in Industrial Revolution 4.0 Era. Atlantis Press, Vol.358, pp. 294-299.

Sa'adah, Nabitatus. (2014). Kelemahan Penerapan

Closed System serta Implikasinya dalam Pemungutan Bea Perolehan Hak atas Tanah dan Bangunan. Masalah-Masalah Hukum, Vol.43, pp. 132-139.

Sari, R. (2018). Kebijakan Insentif Pajak Bagi Usaha Mikro Kecil dan Menengah. Pusat Penelitian
Badan Keahlian DPR RI, Vol.10, (No.12), pp. 19-24.

Sholihah, Imas. (2017). The Importance of Tax Amnesty Policy in Efforts to Overcome Tax Evasion in Indonesia." Jurnal Dinamika Hukum, Vol.16, (No.3), pp. 273-279.

Siahaan, Marihot P. (2010). Pajak Daerah dan Retribusi Daerah.Jakarta: PT Rajagrafindo Persada.

Suci, Yuli R. (2017). Perkembangan UMKM (Usaha Mikro Kecil Dan Menengah) Di Indonesia. Cano Ekonomos, Vol.6, (No.1), pp. 51-58.

Sulastyawati, Dwi., Aravik, Havis., \& Yunus, Nur Rohim. (2019). The The Existence of Tax as an Instrument of the State Revenue in the Perspectives of Islamic Law and Economics. Research and Analysis J ournal, Vol.2, (No.11), pp. 128-137.

Suyatna, H. (2010). Reorientasi Kebijakan UMKM di Era Asia China Free Trade Area (ACFTA). Jurnal IImu Sosial dan IImu Politik, Vol.13, (No.3), pp. 324-350.

Taufik, Ade I. (2017). Evaluasi Regulasi Dalam Menciptakan Kemudahan Berusaha Bagi UMKM. Jurnal Rechts Vinding: Media Pembinaan Hukum Nasional, Vol.6, (No.3), pp. 369-386.

\section{WAWANCARA}

Lutfi, R. (2020). Bagian AR KPP Semarang Barat, Pada Tanggal 26 Januari 2020 Di Kantor Pelayanan Pajak Pratama Semarang Barat. 